\title{
Investigating the Predictors of Domestic Water Consumption in Urban Households with Children Under-Five Years: A Panel Study in the Atwima Nwabiagya District, Ghana
}

\author{
Leslie Danquah $^{1}$, Esi Awuah ${ }^{2}$, Seth Agyemang ${ }^{1} \&$ Charlotte Monica Mensah ${ }^{1}$ \\ ${ }^{1}$ Department of Geography and Rural Development, Faculty of Social Sciences, Kwame Nkrumah University of \\ Science and Technology, Kumasi, Ghana \\ ${ }^{2}$ University of Energy and Natural Resources, Sunyani, Ghana \\ Correspondence: Leslie Danquah, Department of Geography and Rural Development, Faculty of Social Sciences, \\ Kwame Nkrumah University of Science and Technology, Kumasi, Ghana. Tel: 233-24471-4882. E-mail: \\ kwasileslie@yahoo.com
}

Received: January 23, 2014 Accepted: September 22, 2014 Online Published: August 18, 2015

doi:10.5539/jsd.v8n8p1 URL: http://dx.doi.org/10.5539/jsd.v8n8p1

\begin{abstract}
This panel study investigated the effect of potential predictors on per capita domestic water consumption in the wet and dry seasons. A total of 242 urban households with children under age five were drawn from two urban communities, Abuakwa and Nkawie, in the Atwima Nwabiagya District, Ghana. Data were collected from mothers using interviewer-administered questionnaires and analyzed using correlation and stepwise multiple regression. Mean per capita daily water consumption was estimated at 38.97 and 20.70 liters in the wet $(n=140)$ and dry seasons $(n=235)$, respectively. The volume of the primary water storage vessel, number of water storage containers, and household size were the most significant predictors in the wet season, constituting $16 \%$ of the variation in water consumption. Duration of water storage, household size, number of water service hours, and volume of the primary water storage vessel emerged as the most significant predictors in the dry season, constituting $40 \%$ of the variation in water consumption. Further research that considers a wider range of socio-demographic factors, such as the gender of the household head, culture, religion and water use characteristics of each member of the household are recommended.
\end{abstract}

Keywords: urban water consumption, urban household, predictors, Ghana

\section{Introduction}

Water is an essential component of life. In the first large-scale assessment of domestic water use in Africa, researchers examined the use of water for basic consumption, hygiene, and amenities in domestic life (Thompson et al., 2001). Thereafter, numerous studies on water supply were based on the findings of the Drawers of Water I (DOW I) study (Rosen \& Vincent, 1999). Findings from the DOW I study revealed that increasing the quantity of water used per capita was more important for a household's health and well-being than improving its quality. According to the World Health Organization (WHO), water consumption has direct implications for human health physiologically and in controlling for water-related diseases (WHO, 2003). Nevertheless, few reports are published on the association between water consumption and environmentally related diseases (Aiga et al., 1999). Though it is known that the quantity of water used for domestic purposes and personal hygiene has implications for controlling environmentally related diseases such as diarrhoea (Esrey \& Habicht, 1986; Esrey et al., 1985; Victora et al., 1988; Sandiford et al., 1990), there is much to learn regarding water use within the households that have the most vulnerable members: children under five years. The United Nations World Water Assessment Programme (UN WWAP) (2009:97) noted that "our knowledge of water use is poor" and the limited knowledge of water use patterns inhibits the ability to manage water resources appropriately.

A review of the literature suggests that, from the late 1960s, North American economists forged ahead in investigating the factors influencing domestic water consumption and focused on price and income as a means of regulating water demand (Corbella \& Pujol, 2009). Howe and Linaweaver (1967), Jones and Morris (1984), Arbués et al. (2004), and Garcia and Reynaud (2004) demonstrated that domestic water consumption was 
significantly influenced by price. In addition, Agthe and Billings (1987), Arbués and Villanua (2006), Arbués et al. (2003), Baumann et al. (1998), Gaudin et al. (2001), and Hoffmann et al. (2006) emphasized the influence of income on domestic water consumption. In reality, domestic water consumption is not only influenced by economic factors but also by socio-demographic factors such as population growth (Morehouse et al. 2002), age (Kenney et al., 2008), education (House-Peters et al., 2010), age of building (Chang et al., 2010), and number of bed rooms (Fox et al., 2009).

Recently, there have been demands for further research into socio-demographic factors of water demand to complement information regarding economic factors such as price and income (Corbella \& Pujol, 2009). Furthermore, the Intergovernmental Panel on Climate Change (IPCC) indicated that residential water demand management will be a critical issue that will engage the attention of city authorities due to projected decrease in water supply and increase in demand for water (Bates et al., 2008). In order to address the demand for water, there have also been calls to understand domestic water use behavior and the factors that influence it (Russell \& Fielding, 2010). Attempts by policy makers and urban water planners to effectively manage water resources must consider the factors influencing demand and water consumption behavior from a spatial-temporal perspective. Therefore in order to contribute to the growing body of literature on socio-demographic factors influencing water consumption, we present a panel study of households with children under five. Specifically we asked the following research questions: In households which have children less than five years of age, which factors are significantly associated with domestic water consumption in the wet and dry seasons? Which factors affect domestic water consumption in the wet and dry seasons?

\section{Materials and Methods}

\subsection{Setting}

This panel study was conducted in the Atwima Nwabiagya District $\left(6^{\mathrm{O}} 32^{\prime} \mathrm{N}, 6^{\circ} 75^{\prime} \mathrm{N}\right.$ and $1^{\circ} 45^{\prime} \mathrm{W}, 2^{\circ} 00{ }^{\prime} \mathrm{W}$, $295 \mathrm{~km}^{2}$ ) of the Ashanti Region, Ghana (Figure 1). The district is predominantly urban, with $64 \%$ of residents living in urban communities, and 51\% engaging in agricultural activities (ANDA, 2011:8). Two urban communities, Abuakwa and Nkawie were chosen based on the availability of research logistics and a review of data from the District Health Directorate, which indicated a relatively high prevalence of childhood diarrhoea cases from 2008-2011 (GHS, 2011). This study formed part of a longitudinal study of domestic water use and its relationship with childhood diarrhoea in selected urban communities of the Atwima Nwabiagya District, Ghana. Urban and rural water supply coverage in the study district was estimated at $95 \%$ and $70 \%$, respectively, in 2009 (ANDA 2011:31). The study was conducted in two phases. The first was a household survey in the wet season of 2012 (May-August) and the second was a repeat survey of all enumerated households in the dry season of 2013 (January-February). 


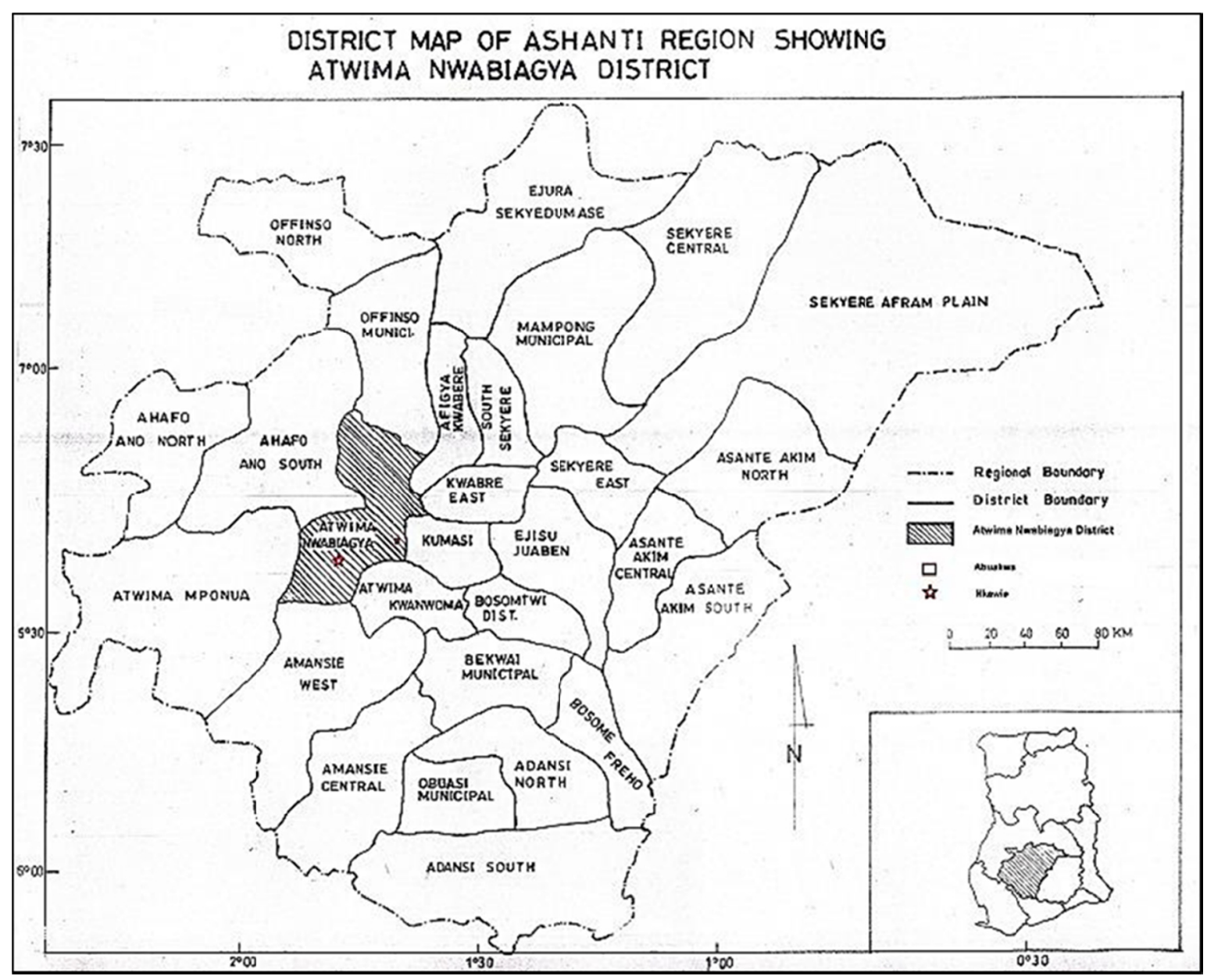

Figure 1.

\subsection{Recruitment and Training of Research Assistants}

Two different sets of research assistants were engaged to assist with data collection. The first assisted with data collection in the wet season whereas the second assisted in the dry season. Each set comprised of six Senior High School (SHS) graduates who were recruited from the study communities. Prior to data collection in each season, the six research assistants were given one-week training in questionnaire administration, interviewing techniques, observation techniques, data management and research ethics. Quantitative data was collected using interviewer-administered questionnaires.

\subsection{Sampling}

\subsubsection{Sample Size}

A sample of 242 households representing $2.14 \%$ of the total number of urban households and $0.68 \%$ of the total number of households in the district were chosen for logistical reasons without power calculations (GSS, 2014:19). Thus, a sample of 175 households in Abuakwa and 67 households in Nkawie, each representing $4 \%$ of the total number of households per community, were studied. Each community was mapped and divided into 10 sectors each using major road networks in the community in order to facilitate household enumeration (Danquah et al., 2014).

\subsubsection{Household Selection}

During enumeration of eligible respondents, we used a systematic random sampling technique. Every other house within a sector was visited and the first household living within the house that satisfied the inclusion criteria was enrolled for the study. A household was deemed eligible if it had at least one child aged five years or younger and if the mother, aged 18 or older, agreed to sign a consent form. This procedure was repeated in each of the study communities until the sample size per community was reached (Danquah et al., 2014). The global positioning system (GPS) location of the household was recorded in a log book and the precoded household 
number was written on the respondent's dwelling wall to facilitate revisits and accurate data entry. All respondents were mothers who had at least one child aged five years or younger.

\subsection{Pilot Study}

The research instruments were pre-tested in Kobeng, a community in the Atwima Nwabiagya District and after a review of the collected data, corrections were made to the research instrument before the start of field data collection in May 2012.

\subsection{Data collection instruments}

Interviewer administered questionnaires were used to collect data on socio-demographic characteristics of respondents and domestic water use behavior at the household level in both wet and dry seasons. It included two sections namely:

1. socio-demographic characteristics such as age of the respondent, level of education, marital status, age of spouse, age of children, number of children less than five years old, level of education of spouse, occupation, number of rooms, length of stay in the dwelling (years), dwelling characteristics; type of roof, type of walls, floor type, ownership of dwelling, household size, and household possessions.

2. water use characteristics such as sources of domestic water, sources of drinking water, size and type of primary water collection vessel, size of the primary water storage vessel, time taken to conduct a return water collection trip, number of water collection trips per day, total amount of water collected per day, payment for water usage, number of days for water storage, water storage frequency and number of functional taps in the household.

\subsection{Statistical Analysis}

Quantitative data on socio-demographic and water consumption characteristics were entered into the Statistical Package for Social Sciences $\left(\right.$ SPSS $^{\circledR}$ ) version 16. Correlation and stepwise multiple regressions were used to examine the relationships between per capita water consumption and eleven potential predictors. The predictors were chosen based on the review of the results of studies conducted by Sandiford et al., (1990); Thompson et al.,(2001); Gazzinelli et al, (1998) and House-Peters and Chang, (2011). Collinearity diagnostics suggested that multicollinearity amongst the variables was not a concern. A stepwise multiple regression was used to determine the predictors of water consumption. Each variable was entered in a sequence and its value was assessed with statistical significance set at $\mathrm{p} \leq 0.05$. The variables that significantly contributed to the model were retained. All other variables were reentered to assess their contributions to the success of the model, and the variables that did not contribute significantly to the model were removed. The stepwise method ensured that only a small possible set of determinants was included in the model, and therefore it also gave the minimum number of variables needed to determine water use (Sandiford et al. 1990; Gazzinelli et al. 1998). Table 1 indicates the variables and the relationship with per capita water consumption. 
Table 1. Hypothesized predictor variables of per capita water consumption in households with children under 5 years

\begin{tabular}{|c|c|c|c|c|}
\hline Variable & $\begin{array}{c}\text { Description used in } \\
\text { SPSS }\end{array}$ & Scale & Coding & $\begin{array}{l}\text { Expected relationship with } \\
\text { water consumption per capita } \\
\text { in wet and dry season }{ }^{\dagger}\end{array}$ \\
\hline $\begin{array}{l}\text { Household } \\
\text { socio-economic status }\end{array}$ & $\begin{array}{l}\text { Household is middle } \\
\text { income or lower }\end{array}$ & Categorical & $\begin{array}{l}\text { Yes }-1 \\
\text { No }-0\end{array}$ & + \\
\hline Mother's educational level & $\begin{array}{l}\text { Mother had no } \\
\text { formal education }\end{array}$ & Categorical & $\begin{array}{l}\text { Yes }-1 \\
\text { No }-0\end{array}$ & + \\
\hline Hours of water service & $\begin{array}{l}\text { Hours of water } \\
\text { service is } 24 \text { hours }\end{array}$ & Categorical & $\begin{array}{l}\text { Yes }-1 \text {; } \\
\text { No }-0\end{array}$ & + \\
\hline $\begin{array}{l}\text { Volume of the primary } \\
\text { water storage vessel. }\end{array}$ & $\begin{array}{l}\text { Volume of water } \\
\text { storage vessel is } \\
\text { above } 40 \text { liters }\end{array}$ & Categorical & $\begin{array}{l}\text { Yes }-1 \\
\text { No }-0\end{array}$ & + \\
\hline $\begin{array}{l}\text { Amount paid for water per } \\
\text { day }(\mathrm{GHC})\end{array}$ & $\begin{array}{l}\text { Amount paid for } \\
\text { water per day }\end{array}$ & Continuous & N/A & \\
\hline Household size & Household size & Continuous & $\mathrm{N} / \mathrm{A}$ & - \\
\hline $\begin{array}{l}\text { Time taken to make a } \\
\text { return water collection trip } \\
\text { (Minutes.) }\end{array}$ & $\begin{array}{l}\text { Total time taken to } \\
\text { walk, get water and } \\
\text { back }\end{array}$ & Continuous & $\mathrm{N} / \mathrm{A}$ & - \\
\hline Number of functional taps & $\begin{array}{l}\text { Number of functional } \\
\text { taps in household }\end{array}$ & Continuous & $\mathrm{N} / \mathrm{A}$ & + \\
\hline $\begin{array}{l}\text { Number of children less } \\
\text { than five years }\end{array}$ & $\begin{array}{l}\text { Number of } \\
\text { under-five year olds }\end{array}$ & Continuous & $\mathrm{N} / \mathrm{A}$ & - \\
\hline $\begin{array}{l}\text { Number of water storage } \\
\text { vessels }\end{array}$ & $\begin{array}{l}\text { Number of water } \\
\text { storage containers }\end{array}$ & Continuous & $\mathrm{N} / \mathrm{A}$ & + \\
\hline $\begin{array}{l}\text { Duration of water storage } \\
\text { (days) }\end{array}$ & $\begin{array}{l}\text { Length of water } \\
\text { storage }\end{array}$ & Continuous & N/A & - \\
\hline
\end{tabular}

Source: Authors' field survey, 2012; † - Based on review of Thompson et al.,(2001); Sandiford et al., (1990); Gazzinelli et al, 1998 and House-Peters and Chang, (2011).

As shown in Table 1, out of the 11 variables four were re-coded into a binary outcome of 'Yes' (1) and 'No' (0). They were household socio-economic status, mother's educational level, hours of water service and volume of the primary water storage vessel.

Distance was estimated in minutes using reported times given by mothers. Mothers estimated the total volume of water collected a day in the household by using a pictorial guide of locally appropriate water container sizes (UNHCR, 2013:14). Per-capita daily water consumption (1/capita/day) was calculated by dividing the total volume of water used in a day (total daily water consumption) by the total number of members of the household.

\subsubsection{Wealth Index}

Socio-economic status was assessed using a 'wealth index' which was developed using household possessions due to the difficulty encountered in collecting reliable information on incomes during the pretest. Each household's possessions were assigned scores for analysis as follows: bicycle (1), working radio (1), electricity (2), cassette player (2), motor cycle (2), car (3), working television (3), household utensils (3) and refrigerator (4). Roof type: tatch/mud (1), plywood (2), metal (3), tile/concrete (4). Where a household did not own any of the items, a corresponding zero (0) score was given. The wealth index was categorized as follows: 1-4 'Low income', 5-8 'lower middle income', 9-12 'Middle income', 13-16 'Upper middle income', 17-20 'High income' 
and 21 or more 'Very high income' (Thompson et al., 2001; Gazzinelli et al, 1998).

\subsection{Ethical Approval}

Ethical approval was given by the Committee on Human Research, Publication and Ethics (CHRPE), Kwame Nkrumah University of Science and Technology, (CHRPE/AP/187/12). Additional approval was given by the District Health Directorate and the Atwima Nwabiagya District Assembly.

\section{Results}

\subsection{Socio-demographic Background and Water Consumption Characteristics}

The highest number and proportion of urban residents 175 (72.3\%) were located in Abuakwa, followed by 67 (27.7\%) located in Nkawie. Married respondents constituted 207 (85.5\%) of the studied urban population and the mean household size was 5 persons ( \pm 2 S.D), which was higher than the national average of 4.4 persons (GSS, 2013:72). In addition, there were 155 (64.6\%) urban households with only one child less than five years and 203 (84.2\%) households living in single-room apartments. The mean age of mothers in the urban households was 31 years ( \pm 6 S.D) compared to 39 years ( \pm 9 S.D) for their male counterparts. While the majority of mothers, 104 $(43 \%)$, were involved in trading, 76 (31.4\%) were self-employed and $25(10.3 \%)$ were housewives, $98(40.5 \%)$ of their male counterparts were self-employed, $48(19.8 \%)$ were drivers, and $23(9.5 \%)$ were civil servants. With respect to education, a large number of mothers in urban households, $24(10 \%)$, did not have formal education compared to $13(5.8 \%)$ of their male counterparts (Table 2$)$.

A total of 170 households (71\%) used improved sources of drinking water, whereas 70 households $(29 \%)$ used unimproved sources. Latrine ownership, on the other hand, was low as only 20 households (8.3\%) owned a latrine. Consequently, improved sanitation usage was only $8 \%$ (Table 2). In both the wet and dry seasons, the mean number of functional taps in a household was one and it took an average of six minutes to make a return water collection trip in each season. In the wet season, households $(n=186)$ paid an average of $\mathrm{GhC} 2.00$ per day, whereas in the dry season, households $(\mathrm{n}=215)$ paid an average of $\mathrm{GhC} 1.00$ per day. Mean daily water consumption per capita for the wet $(n=140)$ and dry seasons $(n=235)$ was 38.97 and 20.70 liters, respectively (data not shown in the table).

Table 2. Socio-demographic characteristics of households

\begin{tabular}{lll}
\hline Socio-demographic characteristics & $\mathrm{N}=242$ & Per-cent (\%) \\
\hline Sites & 175 & 72 \\
$\quad$ Abuakwa & 67 & 28 \\
$\quad$ Nkawie & 31 years ( \pm 6 S.D) & \\
Mean age of mother $(\mathrm{n}=241)$ & 39 years $( \pm 9$ S.D) & \\
Mean age of father $(\mathrm{n}=210)$ & $18-55$ years & \\
Mother's age range & $5( \pm 2$ S.D) & \\
Mean household size & & 10 \\
Mother completed SHS or higher $(\mathrm{n}=241)$ & 24 & 90 \\
Yes & 217 & \\
No & & 6 \\
Father completed SHS or higher $(\mathrm{n}=226)$ & 13 & 94 \\
Yes & 213 & 42 \\
No & & 21 \\
Occupation of father $(\mathrm{n}=230)$ & 98 & 10 \\
Self employed & 48 & 10 \\
Driver & 23 & 7 \\
Civil servant/gov't. employee & 22 & 10 \\
Farmer & 15 & \\
Trader & 24 & \\
Others & &
\end{tabular}


Occupation of mother

Trader

104

43

Self employed

76

32

Housewife

10

Unemployed

25

22

9.1

Farmer

8

3.3

Sales woman/Service worker

others

$4 \quad 1.6$

3

1

Marital status

Married

Wealth Index $(\mathrm{n}=236)$

Low income

5

3

Middle income

High income

Very high income

20

8

Number of rooms $(n=241)$

1

203

84.2

2

30

12.4

3

7

2.9

Above 3

1

0.4

Number of children below 5 years in household $(n=240)$

1

155

64.6

2

72

30.0

3

6

Above 3

7

2.5

2.9

Water source type $(\mathrm{n}=240)$

Improved

Unimproved

Latrine ownership

Privately owned

Shared

Public toilet

Sanitation type

Improved

20

8

Unimproved

222

92

Source: Authors' field survey 2012; n denotes the number of valid observations. 
Table 3. Correlation matrix of the relationship between per capita water consumption and 11 variables in the wet season

\begin{tabular}{|c|c|c|c|c|c|c|c|c|c|c|c|c|}
\hline Variables & (1) & (2) & (3) & (4) & (5) & (6) & (7) & (8) & (9) & (10) & (11) & (12) \\
\hline $\begin{array}{l}\text { L / capita / day } \\
\text { (Wet season) (1) }\end{array}$ & 1 & & & & & & & & & & & \\
\hline $\begin{array}{l}\text { Household is } \\
\text { middle income or } \\
\text { lower (2) }\end{array}$ & -0.194 & & & & & & & & & & & \\
\hline $\begin{array}{l}\text { Hours of water } \\
\text { service is } 24 \mathrm{hrs} \text { in } \\
\text { wet season (3) }\end{array}$ & 0.138 & 0.007 & & & & & & & & & & \\
\hline $\begin{array}{l}\text { Mother had no } \\
\text { formal education } \\
\text { (4) }\end{array}$ & -0.17 & 0.158 & -0.17 & & & & & & & & & \\
\hline $\begin{array}{l}\text { Volume of storage } \\
\text { vessel is above } 40 \\
\text { liters (5) }\end{array}$ & $0.278^{*}$ & $-0.243 *$ & $0.342^{* *}$ & $-0.364 * *$ & & & & & & & & \\
\hline $\begin{array}{l}\text { Amount paid for } \\
\text { water per day (GH } \\
\text { Cedis) (6) }\end{array}$ & -0.127 & -0.069 & -0.111 & $0.251 *$ & -0.172 & & & & & & & \\
\hline $\begin{array}{l}\text { Household size } \\
\text { (7) }\end{array}$ & -0.133 & -0.200 & -0.113 & 0.068 & $0.228^{*}$ & -0.082 & & & & & & \\
\hline $\begin{array}{l}\text { Total time taken } \\
\text { to walk, get water } \\
\text { and back } \\
\text { (Minutes) (8) }\end{array}$ & -0.003 & -0.115 & 0.054 & -0.005 & $0.214^{*}$ & -0.03 & 0.108 & & & & & \\
\hline $\begin{array}{l}\text { Number of } \\
\text { functional taps in } \\
\text { household (9) }\end{array}$ & -0.106 & 0.208 & 0.141 & -0.064 & 0.072 & 0.221 & -0.181 & -0.084 & & & & \\
\hline $\begin{array}{l}\text { Number of } \\
\text { children less than } \\
\text { five years (10) }\end{array}$ & $-0.206^{*}$ & 0.027 & $-0.224 *$ & $0.325 * *$ & $-0.309 * *$ & 0.103 & $0.225^{*}$ & 0.086 & -0.138 & & & \\
\hline $\begin{array}{l}\text { Number of water } \\
\text { storage containers } \\
\text { (11) }\end{array}$ & 0.19 & 0.078 & -0.068 & 0.152 & -0.167 & -0.138 & 0.159 & -0.022 & -0.042 & 0.041 & & \\
\hline $\begin{array}{l}\text { Duration of water } \\
\text { storage (days) } \\
\text { (12) }\end{array}$ & 0.006 & 0.017 & 0.145 & -0.056 & 0.121 & -0.094 & $-0.262 *$ & -0.115 & $0.215^{*}$ & $-0.218^{*}$ & -0.055 & \\
\hline
\end{tabular}

Source: Authors' field survey, $2012 ;{ }^{*} \mathrm{p} \leq 0.05 ;{ }^{* *} \mathrm{p} \leq 0.01$ 
Table 4. Correlation matrix of the relationship between per capita water consumption and 11 variables in the dry season

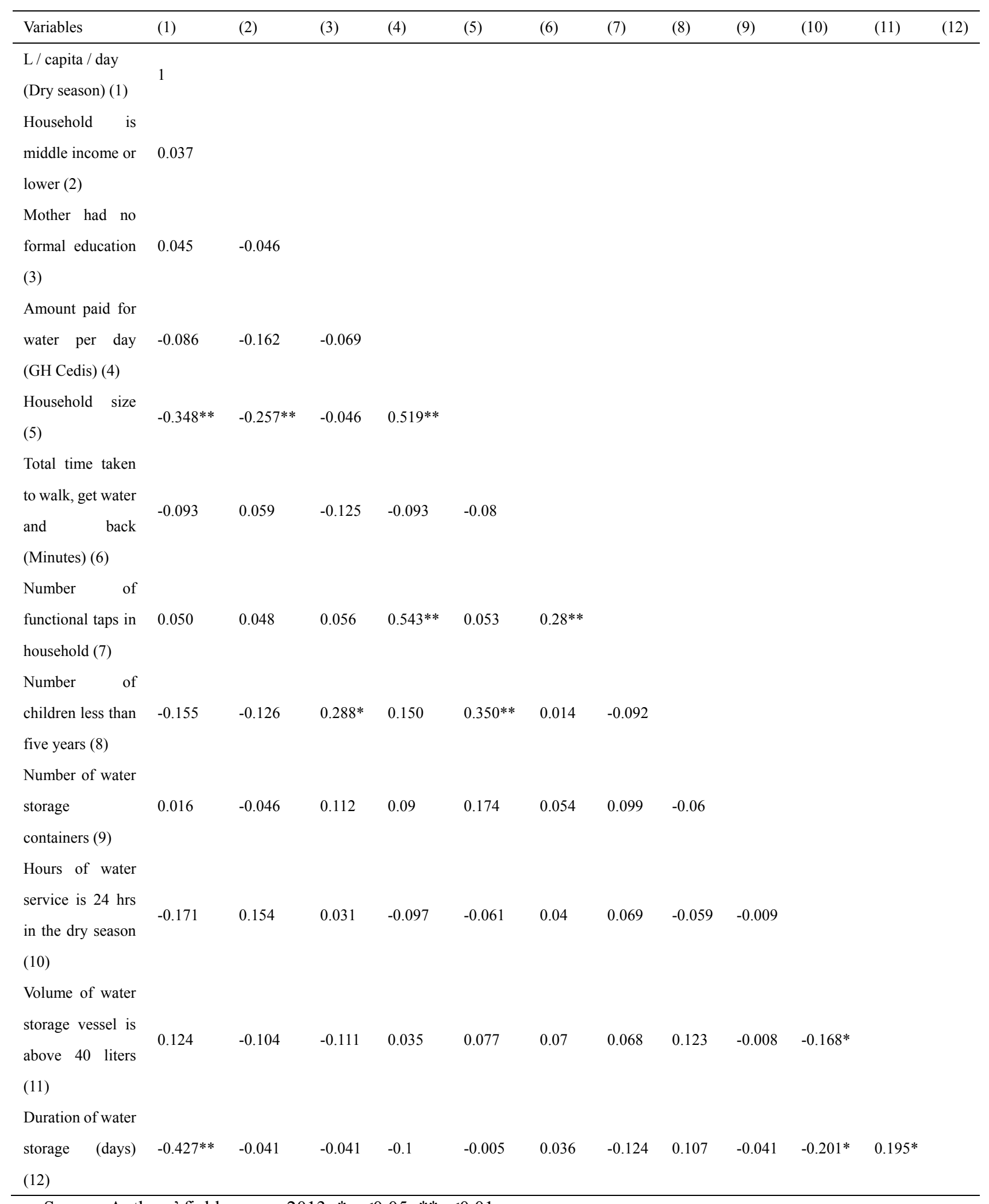

Source: Authors' field survey, 2013; ${ }^{*} \mathrm{p} \leq 0.05 ;{ }^{* *} \mathrm{p} \leq 0.01$ 


\subsection{The Relationship between Per Capita Water Consumption and Hypothesized Factors}

\subsubsection{Wet Season}

From the correlational analysis in Table 3, factors such as household socioeconomic status, mother's educational level, amount paid for water, household size, number of functional taps, and the number of children less than five years showed a negative correlation with per capita water consumption in the wet season. However, only the volume of the primary water storage vessel, number of water storage vessels, and length of water storage showed a positive correlation with per capita water use. Furthermore, the results suggest that only two factors out of 11; the volume of the primary water storage vessel $(r=0.278, p<0.05)$ and the number of children less than five years $(r=-0.206, p<0.05)$, showed a statistically significant correlation with per capita water consumption (Table 3). Studies in rural Nicaragua in Central America have also shown that household size, site of clothes washing, types of water source and distance to water source were negatively correlated with per capita daily domestic water consumption. However, the mother's level of schooling (years), father's level of schooling (years) and ownership of cattle were positively correlated with per capita daily domestic water consumption (Sandiford et al. 1990).

In the wet season, the correlation was statistically significant for the relationship between the volume of the primary water storage vessel and factors such as household wealth $(r=-0.243, p<0.05)$, hours of water service $(\mathrm{r}=0.342, \mathrm{p}<0.01)$, mother's educational level $(\mathrm{r}=-0.364, \mathrm{p}<0.01)$, household size $(\mathrm{r}=0.228, \mathrm{p}<0.05)$, time taken to make a return water collection trip $(r=-0.214, p<0.05)$ and the number of children less than five years $(r=-0.309, p<0.01)$. The number of children less than five years was significantly correlated with factors such as hours of water service $(r=-0.224, p<0.05)$, mother's educational level $(r=0.325, p<0.01)$, volume of the water storage vessel $(r=-0.309, p<0.01)$ and household size $(r=0.225, p<0.05)$.

\subsubsection{Dry Season}

In Table 4, household socioeconomic status, number of functional taps, and volume of the primary water storage vessel showed a positive correlation with per capita water consumption in the dry season. Six factors out of 11 showed a negative correlation with per capita water consumption; namely, amount paid for water, household size, time taken to make a return water collection trip, number of children less than five years, hours of water service, and length of water storage. Only two variables out of 11 showed a statistically significant correlation with water consumption; namely, household size $(r=-0.348, p \leq 0.01)$ and length of water storage $(r=-0.427, p \leq 0.01)$.

In the dry season, the correlation amongst the hypothesized predictors was statistically significant for the relationship between household size and household wealth $(r=-0.257, p<0.01)$, as well as the amount paid for water per day $(\mathrm{r}=0.519, \mathrm{p}<0.01)$. The correlation of the number of water taps was only statistically significant for the amount paid for water $(\mathrm{r}=-0.543, \mathrm{p}<0.01)$ and time taken to make a return water collection trip $(\mathrm{r}=$ $0.28, \mathrm{p}<0.05)$. The number of children less than five years correlated significantly with the mother's educational level $(r=0.288, p<0.05)$ and household size $(r=0.350, p<0.01)$. Duration of water storage was also significantly correlated with per capita water consumption $(\mathrm{r}=-0.427, \mathrm{p}<0.01)$, hours of water service $(\mathrm{r}=$ $-0.201, \mathrm{p}<0.05)$, and the volume of the primary water storage vessel $(\mathrm{r}=0.195, \mathrm{p}<0.05)$.

\subsubsection{Similarities and differences between the Wet and Dry Season}

Comparing the results of the correlational analysis of the two seasons, some similarities and differences emerge. As shown in Table 5, six out of eleven predictors compared to nine out of eleven met our expectation for the wet and dry season respectively. The results suggest that irrespective of the season, the volume of the primary water storage vessel, and the numbers of water storage vessels in the households are both likely to show a positive correlation with per capita water consumption. On the other hand, household size, time taken to make a return water collection trip and the number of children less than five years are all likely to show a negative correlation with per capita water consumption regardless of the season (Table 5). The wet and dry season differed in terms of the direction of relationship between per capita water consumption and household socio-economic status, mother's educational level, hours of water service, number of functional taps and duration of water storage (Table 5). 
Table 5. Summary table showing the nature of the relationship between per capita water consumption and 11 potential predictors in the wet and dry season

\begin{tabular}{|c|c|c|c|}
\hline Potential predictor & $\begin{array}{c}\text { Expected relationship with per } \\
\text { capita water consumption in } \\
\text { wet and dry seasons }\end{array}$ & $\begin{array}{c}\text { Nature of } \\
\text { relationship in the } \\
\text { wet season }\end{array}$ & $\begin{array}{c}\text { Nature of } \\
\text { relationship in the } \\
\text { dry season }\end{array}$ \\
\hline $\begin{array}{l}\text { Household socioeconomic } \\
\text { status }\end{array}$ & + & - & + \\
\hline Mother's educational level & + & - & + \\
\hline Hours of water service & + & + & - \\
\hline $\begin{array}{l}\text { Volume of the primary } \\
\text { water storage vessel. }\end{array}$ & + & $+*$ & + \\
\hline $\begin{array}{l}\text { Amount paid for water per } \\
\text { day }(\mathrm{GHC})\end{array}$ & + & - & - \\
\hline Household size & - & - & $-* *$ \\
\hline $\begin{array}{l}\text { Time taken to make a return } \\
\text { water collection trip } \\
\text { (Minutes.) }\end{array}$ & - & - & - \\
\hline Number of functional taps & + & - & + \\
\hline $\begin{array}{l}\text { Number of children less } \\
\text { than five years }\end{array}$ & - & $-*$ & - \\
\hline $\begin{array}{l}\text { Number of water storage } \\
\text { vessels }\end{array}$ & + & + & + \\
\hline $\begin{array}{l}\text { Duration of water storage } \\
\text { (days) }\end{array}$ & - & + & $-* *$ \\
\hline
\end{tabular}

Source: Authors' field survey, 2012 and 2013

\subsection{Effects of Predictors on Per Capita Domestic Water Consumption}

We conducted stepwise multiple regression analysis to examine the effects of the potential predictors on per capita water consumption in urban households with children under-five years. The wet season model was not statistically significant as a whole when all 11 predictors were assessed together, $\mathrm{R}^{2}=0.12, \mathrm{~F}(11,68)=1.89, \mathrm{p}=$ 0.06 (Table 6). Nevertheless, when assessed with the stepwise multiple regression, the volume of the primary water storage vessel, household size and number of water storage vessels showed statistical significance ( $\mathrm{p} \leq$ 0.05 ) and together they accounted for $16 \%$ of the variation in per capita water consumption in the wet season, $\mathrm{R}^{2}=0.16, \mathrm{~F}(3,68)=5.33, \mathrm{p}=0.002$ (Table 7). Compared to the wet season, a relatively better model was found for the dry season, where the number of service hours, household size, volume of the primary water storage vessel and duration of water storage showed statistical significance (Table 6) and the overall dry season model was also statistically significant; $R^{2}=0.37, F(11,92)=5.87, p=0.000$. Together, the number of service hours, household size, volume of the primary water storage vessel, and duration of water storage showed statistical significance and constituted $40 \%$ of the total variation in per capita water consumption in urban households in the dry season; $\mathrm{R}^{2}=0.40, \mathrm{~F}(4,92)=16.29, \mathrm{p}=0.000$ (Table 7). 
Table 6. Beta coefficients of potential predictors of per capita water consumption in the wet and dry seasons

\begin{tabular}{|c|c|c|c|c|c|c|}
\hline \multirow{2}{*}{ Potential predictors } & \multicolumn{3}{|c|}{ Wet season } & \multicolumn{3}{|c|}{ Dry season } \\
\hline & $\begin{array}{c}\text { Std. Beta } \\
\text { Coefficients }\end{array}$ & $\mathrm{t}$ & $\begin{array}{c}\text { Sig. } \\
\text { (p-value) }\end{array}$ & $\begin{array}{c}\text { Std. Beta } \\
\text { Coefficients }\end{array}$ & $\mathrm{t}$ & $\begin{array}{c}\text { Sig. } \\
\text { (p-value) }\end{array}$ \\
\hline (Constant) & & 2.523 & .015 & & 3.759 & .000 \\
\hline Household is middle income or lower & -.172 & -1.369 & .176 & -.018 & -.204 & .839 \\
\hline Number of service hours is $24 \mathrm{hrs}$ & .017 & .133 & .895 & -.257 & -2.923 & .005 \\
\hline Mother had no formal education & -.023 & -.172 & .864 & .008 & .087 & .931 \\
\hline $\begin{array}{l}\text { Volume of storage vessel is above } 40 \\
\text { liters }\end{array}$ & .369 & 2.440 & .018 & .217 & 2.464 & .016 \\
\hline $\begin{array}{l}\text { Amount paid for water per day } \\
(\mathrm{GHC})\end{array}$ & -.031 & -.241 & .811 & .003 & .024 & .981 \\
\hline Household size & -.331 & -2.438 & .018 & -.416 & -3.734 & .000 \\
\hline $\begin{array}{l}\text { Total time taken to walk, get water } \\
\text { and back (Minutes) }\end{array}$ & -.080 & -.668 & .507 & -.125 & -1.311 & .194 \\
\hline $\begin{array}{l}\text { Number of functional taps in } \\
\text { household }\end{array}$ & -.131 & -1.027 & .309 & .039 & .317 & .752 \\
\hline $\begin{array}{l}\text { Number of children less than five } \\
\text { years }\end{array}$ & -.044 & -.332 & .741 & .008 & .077 & .939 \\
\hline Number of water storage containers & .307 & 2.530 & .014 & .068 & .786 & .434 \\
\hline Duration of water storage (days) & -.103 & -.818 & .417 & -.511 & -5.844 & .000 \\
\hline Adjusted $\mathrm{R}^{2}$ & 0.12 & & & 0.37 & & \\
\hline
\end{tabular}

Source: Authors' field survey, 2012 and 2013; Std - Standardized. 
Table 7. Stepwise multiple regression output for predictors of water consumption per capita in the wet and dry seasons

\begin{tabular}{|c|c|c|c|c|c|}
\hline $\begin{array}{l}\text { Multiple } \\
\text { Regression } \\
\text { method }\end{array}$ & Variables in model & (n) & $\begin{array}{c}\mathrm{R} \\
\text { Square }\end{array}$ & $\begin{array}{l}\text { Adjusted } \\
\qquad \mathrm{R}^{2}\end{array}$ & P-value \\
\hline \multicolumn{6}{|l|}{ Wet season } \\
\hline \multirow{3}{*}{ Stepwise } & 1. Volume of storage vessel is above 40 liters. & 68 & 0.07 & 0.06 & 0.022 \\
\hline & $\begin{array}{l}\text { 2. Volume of storage vessel is above } 40 \text { liters, } \\
\text { Number of water storage containers. }\end{array}$ & 68 & 0.13 & 0.10 & 0.009 \\
\hline & $\begin{array}{l}\text { 3. Volume of storage vessel is above } 40 \text { liters, } \\
\text { Number of water storage containers, Household size. }\end{array}$ & 68 & 0.20 & 0.16 & 0.002 \\
\hline \multicolumn{6}{|l|}{ Dry season } \\
\hline \multirow{4}{*}{ Stepwise } & 1. Duration of water storage (days). & 92 & 0.18 & 0.17 & 0.000 \\
\hline & 2. Duration of water storage (days), Household size. & 92 & 0.30 & 0.28 & 0.000 \\
\hline & $\begin{array}{l}\text { 3. Duration of water storage (days), Household size, } \\
\text { Number of service hours is } 24 \mathrm{hrs} \text {. }\end{array}$ & 92 & 0.38 & 0.36 & 0.000 \\
\hline & $\begin{array}{l}\text { 4. Duration of water storage (days), Household size, } \\
\text { Number of service hours is } 24 \mathrm{hrs} \text {, Volume of water } \\
\text { storage is above } 40 \text { liters. }\end{array}$ & 92 & 0.42 & 0.40 & 0.000 \\
\hline
\end{tabular}

Source: Authors' field survey, 2012 and 2013.

\section{Discussions}

This study investigated the predictors of domestic water consumption in households with children less than five years in the wet and dry seasons. Children less than five years do not live in a vacuum, but are catered for and nurtured by the household. In its consumption of water, the household is influenced by various factors.

We found that the most statistically significant predictors of domestic water consumption in the wet season were the volume of the primary water storage vessel, number of water storage containers, and household size (Table 7) Irrespective of the season, per capita water consumption in households with children under five increased when there was an increase in the volume of the primary water storage vessel, as well as when there was an increase in the number of water storage vessels. This suggests that the ability of a household to store more water is increased when there is an increase in the volume or number of water storage containers. The health implication of the use of large storage containers (above 40 liters) or securing more than one storage container is that it affords the household the ability to collect more water for domestic, as well as hygiene, purposes to curtail diarrhoeal disease transmission through inadequate amounts of safe water. A study by Checkley et al. (2004) showed that children in households with small storage containers had $28 \%$ more diarrhoea episodes than children from households with large containers.

In both seasons, per capita water consumption was low in large sized households but higher in small-sized households. This inverse relationship between per capita water consumption and household size is consistent with studies by Martin (1999) and Keshavarzi et al. (2006) who demonstrated in their studies that percapita water consumption in large families was lower compared to smaller families because the use of water for domestic activities such as home cleaning, gardening, taking care of livestock were relatively independent of family size (Fan et al., 2013).

The significant predictors of domestic water consumption in the dry season were duration of water storage (days), household size, number of service hours, and volume of the primary water storage vessel (Table 7). Duration of water storage was inversely related to per capita water use. As the number of days of water storage increased, the volume of water per capita also decreased. In other words, the longer the time it took for water to be replaced, the smaller the volume of water available for each member of the household. A likely reason is that as water is stored over a period of time without replacement, various members of the household may fetch water and use it 
for other domestic purposes, which reduces the total volume of water available to the household. Whenever any member fetches water from the storage vessel, the total volume is reduced, suggesting that a lesser amount is available for the other household members. Unexpectedly, households that received 24-hour water services had lower per capita water consumption in the dry season. This result may probably be due to intermittent flow of water or low flow rates of the water sources used in the season. Thus, although water may be available at a particular water source 24 hours a day, the total volume that can be collected may not be adequate for the households' daily needs. An implication for using intermittent water supply is that waste water from sources such as septic tanks or domestic drains could seep through cracks in the walls and weak joints when the water pressure is low (WSP, 2010). This could result in the introduction of faecal matter into the water distribution system and possible outbreak of diseases (Hunter et al., 2005; WHO, 2014).

It is known that the quantity of water used for domestic purposes and personal hygiene has implications for controlling environmentally related diseases such as diarrhoea (Esrey et al. 1985; Esrey and Habicht 1986; Victora et al. 1988; Sandiford et al. 1990). According to the WHO, water consumption and hygiene have direct implications for human health physiologically and controlling water-related diseases (WHO, 2003:2). Based on service-level definitions given by Howard and Bartram (2003), 140 (58\%) and 235 (97\%) households in the wet and dry seasons, respectively, had "basic access" to water. Basic access implies that, most likely, not all household water needs were met and the quality of water could not be guaranteed to be safe at the point of consumption. This presupposes that adequate safe water must be provided to secure the health of children in the household because children less than five years have lower immunity levels and are more vulnerable to diseases such as scabies, tinea, and diarrhea, which can be contracted due to inadequate water for personal hygiene.

In this study we found that, the $\mathrm{R}^{2}$ values of the potential predictors did not exceed 0.45 . The low explanatory power in this study was consistent with other studies of domestic water use in Mexico which found an $\mathrm{R}^{2}$ of 0.13 (Corral-Verdugo et al., 2002), 0.22 for a study conducted in Australia (Syme et al., 2004), and 0.37 for another conducted in rural China (Fan et al., 2013). The results from our research therefore suggests that percapita domestic water consumption in households with children less than five years may be influenced by varied factors which necessitates further exploration.

\section{Study Limitations}

Our study has some limitations which need to be duly acknowledged. Data about water use at the household level was collected from the female head of the household therefore the study would have benefited more from the inclusion of the views of all the members of each household. Domestic water consumption estimates were reported by mothers who may have been subject to recall bias. In addition, wealth status in this study was estimated by the categorization of household items that had relatively similar economic values. Also there are potential misspecification errors due to missing explanatory variables.

\section{Conclusions}

The 11 predictors we hypothesized could not satisfactorily predict domestic water consumption in both the wet and dry seasons. Nevertheless, we found that in both seasons, factors such as household size and the volume of the primary water storage vessel had a significant relationship with the amount of water consumed per person per day in a household that had children less than five years. We suggest further research on the determinants of water consumption by assessing the influence of socio-demographic factors such as gender of the household head, ethnicity, culture, religion, number of baths per day, residential tenancy arrangements and water use characteristics of each member of the household. We believe these factors may elucidate the determinants of domestic water consumption in households in general and specifically those in which children less than five years live.

\section{Acknowledgements}

We are very grateful to the Atwima Nwabiagya District Health Directorate for their support at the initial stages of our research and Prof. H. Chang for his constructive comments on the manuscript.

\section{References}

Agthe, D. E., \& Billings, R. B. (1987). Equity, price elasticity, and household income under increasing block rates for water. American Journal of Economics and Sociology, 46(3), 273-286. http://dx.doi.org/10.1111/j.1536-7150.1987.tb01966.x

Aiga, H., Arai, Y., Marui, E., \& Umenai, T. (1999). Impact of improvement of water supply on reduction of diarrhoeal incidence in a squatter area of Manila. Environmental Health and Preventive Medicine, 4(3), 111-116. http://dx.doi.org/10.1007/BF02932265 
ANDA. (2011). Atwima Nwabiagya District profile. Nkawie: Atwima Nwabiagya District Assembly.

Arbués, F., \& Villanua, I. (2006). Potential for pricing policies in water resource management estimation of urban residential water demand in Zaragoza, Spain. Urban Studies, 43(13), 2421-2442. http://dx.doi.org/10.1080/00420980601038255

Arbués, F., Barberan R., \& Villanua, I. (2004). Price impact on urban residential water demand: A dynamic panel data approach. Water Resources Research, 40, 1-9.

Arbués, F., García-Valiñas, M. A., \& Martínez-Espiñeira, R. (2003). Estimation of residential water demand: a state-of-the-art review. The Journal of Socio-Economics, 32, 81-102. http://dx.doi.org/10.1016/S1053-5357(03)00005-2

Bates, B. C., Kundzewicz, Z. W., Wu, S., \& Palutikof, J. P. (2008). Climate Change and Water. Technical Paper of the Intergovernmental Panel on Climate Change. Geneva: IPCC Secretariat.

Baumann, D. D., Boland, J., \& Hanemann, W. M. (1998). Urban water demand management and planning. New York, McGraw-Hill.

Chang, H., Parandvash, H., \& Shandas, V. (2010), Spatial variations of single - family residential water consumption in Portland, Oregon. Urban Geography, 31, 953-972. http://dx.doi.org/10.2747/0272-3638.31.7.953

Checkley, W., Gilman, R. H., Black, R. E., Epstein, L. D., Cabrera, L., Sterling, C. R., \& Moulton, L. H. (2004). Effect of water and sanitation on child health in a poor Peruvian peri-urban community. Lancet, 363, 112-118. http://dx.doi.org/10.1016/S0140-6736(03)15261-0

Corbella, H. C., \& Pujol, D. S. (2009). What lies behind domestic water use? A review essay on the drivers of domestic water consumption. Boletin de la A.G.E.N. 50, 297-314.

Corral-Verdugo, V., Frias-Armenta, M., Perez - Urias, F., Orduna-Cabrera, V., \& Espinoza-Gallengo, N. (2002). Residential water consumption, motivation for conserving and the continuing tragedy of the commons. Environmental Management, 30, 527-535. http://dx.doi.org/10.1007/s00267-002-2599-5

Danquah, L., Awuah, E., Mensah., C. M., \& Agyemang, S. (2014). Sanitation and Hygiene Practices in Relation to Childhood Diarrhoea Prevalence: The Case of Households with Children under-Five Years in Ghana. Science Journal of Public Health, 2(2), 119-125.

Esrey, S. A., \& Habicht, J. P. (1986). Epidemiologic evidence for health benefits from improved water and sanitation in developing countries. Epidemiological Review, 8, 117-128.

Esrey, S. A., Feachem, R. G., \& Huges, J. M. (1985). Interventions for the control of diarrhoeal diseases among young children: improving water supplies and excreta disposal facilities. Bulletin of World Health Organization, 63, 757-772.

Fan, L., Wang, F., Geissen, V., Ritsema, C. J. (2013). Factors affecting domestic water consumption in rural households upon access to improved water supply: Insights from the Wei River Basin, China. PLOS ONE, 8(8). http://dx.doi.org/10.1371/journal.pone.0071977

Fox, C., McIntosh, B. S., \& Jeffrey, P. (2009). Classifying households for water demand forecasting using physical property characteristics. Land Use Policy, 26, 558-568. http://dx.doi.org/10.1016/j.landusepol.2008.08.004

Garcia, S., \& Reynaud, A. (2004). Estimating the benefits of efficient water pricing in France. Resource and Energy Economics, 26, 1-25. http://dx.doi.org/10.1016/j.reseneeco.2003.05.001

Gaudin, S., Griffin, R. C., \& Sickles, R. C. (2001). Demand specification for municipal water management: evaluation of the Stone-Geary form. Land Economics, 77, 399-422. http://dx.doi.org/10.2307/3147133

Gazzinelli, A., Souza, M. C., Nascimento, I., Ribeiro Sa, T., Cadete, M. M. M., \& Kloos, H. (1998). Domestic water use in a rural village in Minas Gerais, Brazil, with an emphasis on spatial patterns, sharing of water and factors in water use. Cad.Saude Publica, Rio de Janeiro, 14, 256-277.

Ghana Health Service (GHS). (2011). Health Information Unit Data set. Kumasi: Ghana Health Service.

Ghana Statistical Service (GSS). (2013). 2010 Population and housing census: National Analytical Report. Accra: Ghana Statistical Service.

GSS. (2014). 2010 Population and housing census. District Analytical Report, Atwima Nwabiagya District. Ghana Statistical Service, Accra. 
Hoffmann, M., Worthington, A., \& Higgs, H. (2006). Urban water demand with fixed volumetric charging in a large municipality: the case of Brisbane, Australia. The Australian Journal of Agricultural and Resource Economics, 50, 347-359. http://dx.doi.org/10.1111/j.1467-8489.2006.00339.x

House-Peters, L., \& Chang, H. (2011). Urban water demand modeling: Review of concepts, methods, and organizing principles, Water Resources Research, 47.

House-Peters, L., Pratt, B., \& Chang, H. (2010). Effects of urban spatial structure, socio-demographics, and climate on residential water consumption in Hillsboro, Oregon. Journal of the American. Water Resources Association, 46(3), 461-472.

Howard, G., \& Bartram, J. (2003). Domestic Water Quantity, Service Level and Health. New York: World Health Organization.

Howe, C. W., \& Linaweaver, F. P. (1967). The impact of price on residential water demand and its relation to system design and price structure. Water Resources Research, 3, 13-32. http://dx.doi.org/10.1029/WR003i001p00013

Hunter, P. R, Chalmers, R. M., Hughes, S., \& Syed, Q. (2005). Self-reported diarrhea in a control group: A strong association with reporting of low-pressure events in tap water. Clinical Infectious Diseases, 40, 32-34. http://dx.doi.org/10.1086/427750

Jones, C. V., \& Morris, J. (1984). Instrumental prices estimates of residential water demand. Water Resources Research, 20(2), 197-202. http://dx.doi.org/10.1029/WR020i002p00197

Kenney, S. D., Goemans, C., Klein, R., Lowery, J., \& Reidy, K. (2008). Residential water demand management: Lessons from Aurora, Colorado. Journal of the American Water Resources Association, 44(1), 192-207. http://dx.doi.org/10.1111/j.1752-1688.2007.00147.x

Keshavarzi, A. R., Sharifzadeh, M., Kamgar Haghighi, A. A., Amin, S., Keshtkar, Sh., \& Bamdad, A. (2006). Rural domestic water consumption behaviour: A case study in Ramjerd area, Fars province, I.R. Iran. Water Research, 40, 1173-1178. http://dx.doi.org/10.1016/j.watres.2006.01.021

Martin., N. (1999). Population, households and domestic water use in countries in the Mediterranean Middle East (Jordan, Lebanon, Syria, the West Bank, Gaza and Israel). International Institute for Applied Systems Analysis Report. Schlossplatz 1, A-2361 Laxenburg, Austria.

Morehouse, B. J., Carter, R. H., \& Tschakert, P. (2002). Sensitivity of urban water resources in Phoenix, Tucson, and Sierra Vista, Arizona, to severe drought, Climate Research, 21(3), 283-297. http://dx.doi.org/10.3354/cr021283

Rosen, S., \& Vincent, J. R. (1999). Household water resources and rural productivity in sub-Saharan Africa: A review of the evidence. Development Discussion Paper No. 673. Harvard Institute for International Development.

Russell, S., \& Fielding, K. (2010). Water demand management research: A psychological perspective. Water Resources Research, 46. http://dx.doi.org/10.1029/2009WR008408

Sandiford, P., Gorter, A. C., Orozco, J. G., \& Pauw, J. P. (1990). Determinants of domestic water use in rural Nicaragua. Journal of Tropical Medicine and Hygiene, 93(6), 383-389.

Syme, G. J., Shao, Q., Po, M., \& Campbell, E. (2004). Predicting and understanding home garden water use. Landscape Urban Planning, 68, 121-128. http://dx.doi.org/10.1016/j.landurbplan.2003.08.002

Thompson, J., Porras, I. T., Tumwine, J. K, Mujwahuzi, M. R., Katui-Katua, M., Johnstone, N., \& Wood, L. (2001). Drawers of water II. 30 years of change in domestic water use and environmental health in East Africa. International Institute for Environment and Development. Nottingham: Russell Press.

UN WWAP. (2009). United Nations World Water Assessment Programme. The World Water Development Report 3: Water in a changing world. Paris: UNESCO.

UNHCR. (2013). Standardized expanded nutrition survey (SENS) guidelines for refugee populations, Version 2, Module 5. Water, sanitation and hygiene: A practical step - by - step guide. Geneva: United Nations High Commissioner for Refugees.

Victora, C. G., Vaughan, J. P., Nobre, L. C., Lombard, L. C., Teixeira, A. M. B., Fuchs, S. C., Moreira, L. B., \& Barros, F. C. (1988). Infant mortality due to diarrhoea in relation to the risk of water supply, sanitation and housing. International Journal of Epidemiology, 17(3), 651-654. http://dx.doi.org/10.1093/ije/17.3.651 
WHO. (2003). Domestic water quantity, service level and health. Geneva: World Health Organization.

WHO. (2014). Water safety in distribution systems. Geneva: World Health Organization.

WHO/UNICEF. (2010). Progress on sanitation and drinking-water, 2010 update. Geneva: World Health Organization.

World Bank. (2006). World Development Indicators. Washington, DC: The World Bank.

WSP. (2010). The Karnataka urban water sector improvement project: $24 \times 7$ water supply is achievable. Water and Sanitation Programme, New Delhi: The World Bank.

\section{Copyrights}

Copyright for this article is retained by the author(s), with first publication rights granted to the journal.

This is an open-access article distributed under the terms and conditions of the Creative Commons Attribution license (http://creativecommons.org/licenses/by/3.0/). 